\title{
Anti-inflammatory Activity of Stachys Pilifera Benth
}

\author{
Heibatollah Sadeghi ${ }^{1,2}$; Vahid Zarezade ${ }^{3}$; Hossein Sadeghi ${ }^{1{ }^{*}}$; Mehdi Akbartabar Toori ${ }^{4}$; \\ Mehrzad Jafari Barmak ${ }^{2}$; Arsalan Azizi ${ }^{5}$; Mehdi Ghavamizadeh ${ }^{3}$; Mostafa Mostafazadeh ${ }^{3}$ \\ ${ }^{1}$ Medicinal Plants Research Center, Yasuj University of Medical Sciences, Yasuj, IR Iran \\ ${ }^{2}$ Cellular and Molecular Research Center, Yasuj University of Medical Sciences, Yasuj, IR Iran \\ ${ }^{3}$ Student Research Committee, Yasuj University of Medical Sciences, Yasuj, IR Iran \\ 4 Student Research Committee, Yasuj University of Medical Sciences, Yasuj, IR Iran
${ }^{5}$ Social Determinants of Health Research Center, Yasuj University of Medical Sciences, Yasuj, IR Iran \\ ${ }^{5}$ Social Determinants of Health Research Center, Yasuj University of Medical Sciences, Yasuj, IR Iran \\ ${ }^{*}$ Corresponding Author: Hossein Sadeghi, Medicinal Plants Research Center, Yasuj University of Medical Sciences, Yasuj, IR Iran. Tel: +98-7413346070, Fax: +98-7413346071, E-mail: \\ h_sadeghi_m@yahoo.com
}

Received: April 3, 2014; Revised: May 7, 2014; Accepted: June 30, 2014

\begin{abstract}
Background: Stachys piliferaBenth has long been used to treat infectious diseases as well as respiratory and rheumatoid disorders in Iranian folk medicine. Antioxidants, antitumor, and antimicrobial properties of the plant have been reported.

Objectives: This experimental study was designed to evaluate systemic and topical anti-inflammatory effects of the hydro-alcoholic extract from aerial parts of Stachys pilifera (HESP).

Materials and Methods: Anti-inflammatory effects of HESP was studied in four well-known animal models of inflammation, including carrageenan- or formalin-induced paw edema in rat (thirteen groups, 6 rats per each group), and 12-O-tetradecanoylphorbol-13-acetate (TPA)- or xylene-induced ear edema in mouse (ten groups, 6 mice per each group). The rats received HESP (50-400 mg/kg) orally 45 minutes before the subplantar injection of carrageenan or formalin. In TPA or xylene tests, $\operatorname{HESP}(1,2.5$, and $5 \mathrm{mg} /$ ear $)$ was applied topically simultaneous with these phlogistic agents on the ear mice. Finally, pathological examination of the inflamed tissues (paw and ear) was carried out.

Results: Acute toxicity study of the extract showed that no rats were killed at $5000 \mathrm{mg} / \mathrm{kg}$ (LD50 > 5000 mg/kg). The extract (100 and $200 \mathrm{mg} / \mathrm{kg}$ ) significantly suppressed carrageenan-induced paw edema 1, 2, 3, and 4 hours after carrageenan challenge in comparison with the control group $(\mathrm{P}<0.001)$. The HESP $(100 \mathrm{and} 200 \mathrm{mg} / \mathrm{kg})$ also produced a considerable antiedematogenic effect in the formalin test over a period of 24 hours $(\mathrm{P}<0.01)$. Furthermore, topical administration of the HESP $(1,2.5$, and $5 \mathrm{mg} /$ ear $)$ inhibited TPA- and xyleneinduced ear edema in comparison with the control group $(\mathrm{P}<0.001)$. The pathological analysis of the paws and ears revealed that HESP was capable of reducing tissue destruction, cellular infiltration, and subcutaneous edema induced by the indicated phlogistic agents. Conclusions: The present data confirmed systemic and topical anti-inflammatory effects of Stachys pilifera which is comparable to indomethacin.
\end{abstract}

Keywords:Anti-inflammatories; Carrageenan; Formalin; Stachys; 12-O-Tetradecanoylphorbol-13-Acetate

\section{Background}

Inflammation is a natural body response to some harmful stimuli such as irritants, damaged cells, pathogens, and thermal or mechanical injury in order to restore the body's homeostasis (1). Various pathological states such as multiple trauma, acute transplant rejection, ischemia reperfusion injury, atherosclerotic heart disease, and cancer have been shown to initiate systemic or local inflammation (1-3). During the inflammation process, leukocytes are migrated to the site of injury and some kinds of cytokines such as interleukin-1 $\beta$ (IL-1 $\beta$ ) and tumor necrosis factor- $\alpha$ (TNF- $\alpha$ ) are released. Moreover, reactive oxygen species (ROS) are produced during inflammatory reaction $(3,4)$.

Today, non-steroidal anti-inflammatory drugs (NSAIDs) and glucocorticoids are the main options for treatment of inflammatory disorders (5). Nevertheless, prescription of these anti-inflammatory agents may produce some se- rious side effects such as peptic ulcer, renal dysfunction, and cardiovascular problems (6). Thus, it seems necessary to find a new anti-inflammatory drug with fewer complications than NSAIDs or glucocorticoids, particularly from natural origins.

The genus Stachys (Lamiaceae) contains about 300 species and extensively distributed in tropical and subtropical countries (7). This genus in Iran is represented by 34 species that 13 of them are endemic $(8,9)$. Phytochemical evaluation of Stachys species has been confirmed the presence of flavonoids, phenylethanoid glycosides, diterpenes, saponins, terpenoids, and steroids in them (10-12). Several biological studies have been reported considerable anti-inflammatory, antioxidant, antibacterial, and anti-hepatitis effects of this genus (13-17). Stachys pilifera Benth is one of the endemic species in Iran and aerial parts of this plant are used in Iranian folk medicine, as

Copyright ( 2014, Iranian Red Crescent Medical Journal; Published by Kowsar. This is an open-access article distributed under the terms of the Creative Commons Attribution-NonCommercial 4.0 International License (http://creativecommons.org/licenses/by-nc/4.0/) which permits copy and redistribute the material just in noncommercial usages, provided the original work is properly cited. 
herbal tea, for the treatment of various disorders such as asthma, rheumatoid arthritis, and infections (8). A biological study reported the potent antioxidant, antimicrobial, and antitumor activities of the n-butanolic extract of Stachys pilifera in vitro conditions (18).

\section{Objectives}

To our knowledge, there is no report on the anti-inflammatory potential of Stachys pilifera in the literature. Hence, the objective of the present study was to investigate the systemic and local anti-inflammatory effects of HESP (hydro-alcoholic extract from aerial parts of Stachys pilifera) in different experimental models of inflammation.

\section{Materials and Methods}

This experimental study was performed at Yasuj University of Medical Sciences, Yasuj, Iran from December 2013 to March 2014. The study has been approved by the Ethics Committee of Yasuj University of Medical Sciences (Code: 92/6/2/5) in August 2013 and exactly performed according to the "Principles of Laboratory Animal Care" (NIH Publication No. 86-23).

\subsection{Plant Materials}

Aerial parts of Stachys pilifera, including stems and leaves were collected during May 2013 from the suburbs of Yasuj, Iran. The plant was authenticated by Dr. A. Jafari from Department of Botany, Center for Research in Natural Resource and Animal Husbandry, Yasuj University, Yasuj, Iran, where a voucher specimen (herbarium No.1897) was deposited. The collected aerial parts of Stachys pilifera were neatened, shade dried, and powdered.

\subsection{Extract Preparation}

The powdered plant (200 g) was extracted two times with $1000 \mathrm{~mL}$ mixture of EtOH-H2O (7:3) at $45^{\circ} \mathrm{C}$ for 48 h. The extract was filtered and organic solvent was completely evaporated under reduced pressure in a rotary evaporator (Hyedolph, type: Heizbad Hei-VAP, Germany) at $60^{\circ} \mathrm{C}$. Next, the concentrated extract was dried at room temperature. The average yield ratio of the hydroalcoholic extract was about $20.3 \%$.

\subsection{Experimental Animals}

Adult male Wistar rats (200-250 g) and adult male Swiss albino mice (25-35 g) were obtained from Pasteur Institute of Iran (Tehran, Iran). The animals were randomly (by simple randomization) divided into groups, six per each $(17,19-21)$. The animals were kept under a 12:12 h light/dark cycle at $24 \pm 2{ }^{\circ} \mathrm{C}$ and allowed free access to normal diet and water.

\subsection{Grouping}

Sample size was calculated as five animals per group by the following formula:
$\mathrm{N}=\left[(\mathrm{Z}+\mathrm{Z}) 2 \mathrm{Sd}^{2}\right] \mathrm{d}^{2}$

Where $Z_{\alpha}=1.96, Z_{\beta}=0.84, S d=0.22$ and $d=0.4$. However we assign six animals to each group. The expected power was considered as $80 \%$.

\subsection{Chemicals}

Formalin and xylene were obtained from Merck (Darmstadt, Germany). Carrageenan (lambda) was purchased from Fluka Chemical (Switzerland). Indomethacin and TPA (12-O-tetradecanoylphorbol-13-acetate) were purchased from Sigma-Aldrich (St. Louis, MO, USA).

\subsection{Carrageenan-Induced Paw Edema in Rats}

The method of acute inflammation used in this work was similar to that described in our previous works (22, 23). Rats were randomly allocated to six groups of six animals; including control group (vehicle group); treatment groups $(50,100,200$, and $400 \mathrm{mg} / \mathrm{kg})$, and indomethacin group $(10 \mathrm{mg} / \mathrm{kg}$ ), as the standard drug. The indicated groups were orally treated with vehicle, HESP, or indomethacin 45 minutes prior to carrageenan injection. For induction of inflammation, the rats received an injection of $100 \mu \mathrm{L}$ of $1 \%(\mathrm{w} / \mathrm{v})$ suspension of $\chi$-carrageenan in saline, into the plantar side of right hind paw (24). The paw thickness was measured from the ventral to the dorsal surfaces using a digital caliper (Mitutoyo, Japan) immediately before carrageenan challenge and after that at 1, 2, 3, and 4 hours time. Data were expressed as the variation in the paw thickness (mm) and compared to pre-injection values (25). At the end of the experiment, the animals were euthanized by diethyl ether and the inflamed paws were removed and fixed in 10\% formaldehyde solution for histological examination.

\subsection{Formalin-Induced Edema in the Rat Paw}

Animals were randomly allocated to four groups of six rats, including control group (vehicle group), treatment groups (100 and $200 \mathrm{mg} / \mathrm{kg}$ ), and indomethacin group $(10 \mathrm{mg} / \mathrm{kg})$. Paw edema was induced in male Wistar rats by injection of $100 \mu \mathrm{L}$ of formalin $2 \%$ into the plantar side of right hind paw (26). Vehicle, extract (100 and $200 \mathrm{mg}$ / $\mathrm{kg})$, and indomethacin $(10 \mathrm{mg} / \mathrm{kg}$ ) groups were gavaged 45 minutes before formalin injection. The thickness of paw was recorded 1, 2, 3, 4 and 24 hours after formalin challenge.

\subsection{TPA-Induced Mouse Ear Edema}

Adult male Swiss albino mice (25-35 g) were randomly divided into five groups of 6 animals. Ear edema was induced on the anterior and posterior surfaces of the right ear of the mice by the topical application of $2.5 \mu \mathrm{g} /$ ear of TPA dissolved in $20 \mu \mathrm{L}$ of acetone (27). Both extract (1, 2.5, and $5 \mathrm{mg} /$ ear) and indomethacin ( $0.5 \mathrm{mg} / \mathrm{ear}$ ) were also dissolved in acetone and were applied simultaneously with TPA. The animals were euthanized 4 hours after the 
TPA application, and two ear punches (6 mm diameter) were taken from each mouse. Edema was expressed as the difference between the weight (mg) of punched ears. Three ear samples were fixed in formalin $10 \%$ for histological examination.

\subsection{Xylene-Induced Mouse Ear Edema}

Adult male Swiss albino mice (25-35 g) were randomly assigned to five groups of 6 animals. Experiments were carried out according to Shang et al. method (28). The acute inflammation was induced on the anterior and posterior surfaces of the right ear by the topical application of 30 $\mu \mathrm{L} /$ ear of xylene. The extract $(1,2.5$, and $5 \mathrm{mg} /$ ear $)$ or indomethacin (0.5 mg/ear) were applied simultaneously with xylene. One hour later, the animals were euthanized and two ear punches ( $6 \mathrm{~mm}$ diameter) were taken from each mouse and weighed. The increase in the weight of the right ear punch compared to the left ear indicated the edema.

\subsection{Histological Examination}

For histological assessment, three samples of the inflamed ears or paws from the control and the extract treated groups were taken and fixed in 10\% formaldehyde for one week. Then, the fixed tissues were embedded in paraffin and cut into 3-4 $\mu \mathrm{m}$ sections. The slices were mounted on the glass slides, stained with hematoxylin and eosin and finally examined by a pathologist in a blinded way.

\subsection{Ulcerogenic Effect}

After evaluation of the paw edema in the carrageenan test, the animals were euthanized by diethyl ether. The stomachs were taken and cut along the greater curvature. Next, the mucosal surface was washed with normal saline and observed with a convex lens (magnification 10×) for possible injuries or bleeding (29).

\subsection{Acute Toxicity}

In order to determine the LD50 of HESP, three groups of rats $(n=6)$ received the extract $(1000,3000$, and 5000 $\mathrm{mg} / \mathrm{kg}$, orally). The animals were observed for behavior changes and mortality for 48 hours (30).

\subsection{Statistical Analysis}

The data are presented as the mean and standard error of the mean (Mean \pm SEM). The normality of the data has been checked by Kolmogorov-Smirnov test, using SPSS 13.0 software and all variables had normal distribution. The differences between the control and treatment groups were tested by 1-way analysis of variance (ANOVA) followed by the Tukey post-hoc test. $\mathrm{P}<0.05$ was considered to show significant differences for all comparisons.

\section{Results}

\subsection{Effect of HESP on Carrageenan-Induced Paw Edema in Rats}

As shown in Table 1, oral treatment of the animals with HESP at doses of 100 and $200 \mathrm{mg} / \mathrm{kg}$ produced a significant inhibitory effect on carrageenan-induced paw edema compared to the control group $(\mathrm{P}<0.05, \mathrm{P}<0.01$, and $\mathrm{P}<0.001)$. The anti-inflammatory effect of HESP began immediately after carrageenan injection and lasted over 4 hours. The dose of $50 \mathrm{mg} / \mathrm{kg}$ HESP also reduced the paw thickness; however, this effect was not statistically significant. Oral administration of HESP (400 mg/kg) had no suppressive effect on the carrageenan-induced paw inflammation. Oral administration of indomethacin, (10 $\mathrm{mg} / \mathrm{kg}$ ) also showed a significant inhibitory effect on the paw swelling $(\mathrm{P}<0.001)$.

\subsection{Effect of HESP on Formalin-Induced Paw Ede- ma}

As presented in Table 2, subplantar injection of formalin $(2 \%, 100 \mu \mathrm{L})$ produced a prominent inflammation, began

Table 1. Effects of the Hydroalcoholic Extract of Stachys pilifera $(50,100,200$, and $400 \mathrm{mg} / \mathrm{kg}$ ) and Indomethacin (10 mg/kg) on Carrageenan-induced Paw Edema in Rats ${ }^{\text {a }}$

\begin{tabular}{|c|c|c|c|c|c|}
\hline \multirow[t]{2}{*}{ Group } & \multirow[t]{2}{*}{ Dose, mg/kg } & \multicolumn{4}{|c|}{ Increase in Paw Thickness, mm } \\
\hline & & $\mathbf{1 h}$ & $\mathbf{2} \mathbf{h}$ & $3 \mathbf{h}$ & $4 \mathrm{~h}$ \\
\hline Control & - & $1.14 \pm 0.15$ & $1.73 \pm 0.12$ & $1.60 \pm 0.10$ & $1.45 \pm 0.10$ \\
\hline Indomethacin & 10 & $0.26 \pm 0.04^{b}$ & $0.86 \pm 0.10^{b}$ & $0.55 \pm 0.02^{b}$ & $0.36 \pm 0.07^{b}$ \\
\hline \multicolumn{6}{|c|}{ Hydroalcoholic extract of Stachyspilifera } \\
\hline & 50 & $0.83 \pm 0.10$ & $1.67 \pm 0.26$ & $1.38 \pm 0.20$ & $1.20 \pm 0.12$ \\
\hline & 100 & $0.46 \pm 0.09^{c}$ & $1.16 \pm 0.04$ & $1.10 \pm 0.03^{d}$ & $0.90 \pm 0.09^{d}$ \\
\hline & 200 & $0.41 \pm 0.13^{\mathrm{C}}$ & $0.91 \pm 0.13^{b}$ & $0.72 \pm 0.05^{b}$ & $0.51 \pm 0.07^{b}$ \\
\hline & 400 & $0.90 \pm 0.10$ & $1.84 \pm 0.12$ & $1.61 \pm 0.16$ & $1.65 \pm 0.16$ \\
\hline
\end{tabular}

\footnotetext{
a Values are expressed as Mean \pm S.E.M. $(n=6)$.

${ }^{\mathrm{P}}<0.001$ statistically significant relative to the control.

${ }^{\mathrm{C}} \mathrm{P}<0.01$ statistically significant relative to the control.

$\mathrm{d}_{\mathrm{P}<0.05}$ statistically significant relative to the control.
} 
Table 2. Effects of the Hydroalcoholic Extract of Stachys pilifera (100 and $200 \mathrm{mg} / \mathrm{kg}$ ) and Indomethacin (10 mg/kg) on FormalinInduced Paw Edema in Rats ${ }^{a}$

\begin{tabular}{|c|c|c|c|c|c|c|}
\hline \multirow[t]{2}{*}{ Group } & \multirow[t]{2}{*}{ Dose, $\mathrm{mg} / \mathrm{kg}$} & \multicolumn{5}{|c|}{ Increase in Paw Thickness, mm } \\
\hline & & $\mathbf{1 h}$ & $\mathbf{2} \mathbf{h}$ & $\mathbf{3 h}$ & $4 \mathrm{~h}$ & $24 \mathrm{~h}$ \\
\hline Control & - & $1.26 \pm 0.13$ & $1.29 \pm 0.18$ & $1.40 \pm 0.16$ & $1.48 \pm 0.14$ & $2.22 \pm 0.12$ \\
\hline Indomethacin & 10 & $0.82 \pm 0.10$ & $0.85 \pm 0.16$ & $0.76 \pm 0.13 \mathrm{~b}$ & $0.71 \pm 0.14^{\mathrm{c}}$ & $1.37 \pm 0.11^{\mathrm{c}}$ \\
\hline \multicolumn{7}{|c|}{ Hydroalcoholic extract of Stachyspilifera } \\
\hline & 100 & $0.87 \pm 0.0$ & $0.57 \pm 0.11 \mathrm{~b}$ & $0.42 \pm 0.08^{\mathrm{C}}$ & $0.35 \pm 0.06^{c}$ & $0.47 \pm 0.04^{\mathrm{c}}$ \\
\hline & 200 & $0.65 \pm 0.14^{b}$ & $0.70 \pm 0.11^{d}$ & $0.59 \pm 0.07^{b}$ & $0.51 \pm 0.03^{c}$ & $1.40 \pm 0.08^{c}$ \\
\hline
\end{tabular}

a Values are expressed as Mean \pm S.E.M. $(n=6)$.

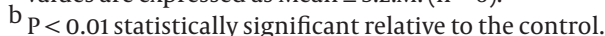

${ }^{\mathrm{C}} \mathrm{P}<0.001$ statistically significant relative to the control.

$\mathrm{d}_{\mathrm{P}<0.05 \text { statistically significant relative to the control. }}$

immediately after formalin injection. The effective doses of HESP (100 and $200 \mathrm{mg} / \mathrm{kg}$ ) in the previous test were applied in the formalin model. The indicated doses of HESP significantly inhibited the development of paw edema at $1,2,3,4$, and $24 \mathrm{~h}$ after injection $(\mathrm{P}<0.01$ and $\mathrm{P}<0.001)$, compared to the control group. As expected, indomethacin (10 $\mathrm{mg} / \mathrm{kg})$ also considerably inhibited the formalininduced paw edema $(\mathrm{P}<0.01$ and $\mathrm{P}<0.001)$.

\subsection{Effect of HESP on TPA-Induced Mouse EarEdema}

The weight of mice's ear drastically increased 4 hours after topical application of TPA. As shown in Table 3, topical application of HESP at doses of 1, 2.5, and $5 \mathrm{mg} /$ ear dosedependently decreased TPA-induced ear edema $(\mathrm{P}<0.05$, $\mathrm{P}<0.01$, and $\mathrm{P}<0.001$, respectively). Topical indomethacin (0.5 mg/ear) also elicited a significant antiedematogenic effect on TPA-induced ear edema $(\mathrm{P}<0.001)$.

\subsection{Effect of HESP on Xylene-Induced Mouse Ear Edema}

Topical application of xylene on the ear of mice in the control group caused a marked increase in the weight of the ears (Table 4). Topical application of $\operatorname{HESP}(1,2.5$, and $5 \mathrm{mg}$ / $\mathrm{kg}$ ) simultaneous with xylene, suppressed xylene-induced ear edema in mice $(\mathrm{P}<0.05$ and $\mathrm{P}<0.01)$. Indomethacin ( $0.5 \mathrm{mg} /$ ear) did not exhibit a considerable anti-inflammatory effect in the model of xylene-induced ear edema.

\subsection{Histological Examination}

As illustrated in Figure 1, histological assessment of the paw tissues showed that subplantar injection of carrageenan has induced hyperplasia, edema, and congestion of vessels. Furthermore, infiltration of inflammatory cells such as lymphocytes and neutrophils into the connective tissues was noticeable. Oral administration of HESP (100 and $200 \mathrm{mg} / \mathrm{kg}$ ) and indomethacin (10 mg/ $\mathrm{kg}$ ) greatly reduced the indicated changes. Ear biopsies of TPA-treated group (Figure 2) showed a marked increase of epidermis thickness, edema, and infiltration of polymorphonuclear (PMN) leukocytes. Topical administration of the $\operatorname{HESP}(1,2.5,5 \mathrm{mg} /$ ear) and indomethacin (0.5mg/ear) could decrease these inflammatory lesions.

Table 3. Effects of the Hydroalcoholic Extract of Stachys Pilifera $(1,2.5$, and $5 \mathrm{mg} /$ ear $)$ and Indomethacin ( $0.5 \mathrm{mg} /$ ear) on 12-OTetradecanoylphorbol-13-Acetate-induced Ear Edema in Mice a

\begin{tabular}{lcc}
\hline Group & Dose, $\mathbf{m g} / \mathbf{e a r}$ & Weight of Ear, mg \\
\hline Control & - & $14 \pm 1.67$ \\
Indomethacin & 0.5 & $5 \pm 1.37^{\mathrm{b}}$ \\
$\begin{array}{l}\text { Hydroalco- } \\
\text { holic extract of } \\
\text { Stachyspilifera }\end{array}$ & & \\
& 1 & $7.8 \pm 1.24^{\mathrm{C}}$ \\
& 2.5 & $7.4 \pm 0.50^{\mathrm{d}}$ \\
& 5 & $2.2 \pm 0.96^{\mathrm{b}}$ \\
\hline
\end{tabular}

a Values are expressed as Mean \pm S.E.M. $(n=6)$.

${ }^{\mathrm{b}} \mathrm{P}<0.001$ statistically significant relative to the control

c $\mathrm{P}<0.05$ statistically significant relative to the control.

d $\mathrm{P}<0.01$ statistically significant relative to the control.

Table 4. Effects of the Hydroalcoholic Extract of Stachys Pilifera $(1,2.5$, and $5 \mathrm{mg} / \mathrm{ear})$ and Indomethacin ( $0.5 \mathrm{mg} /$ ear) on Xyleneinduced Ear Edema in Mice ${ }^{a}$

\begin{tabular}{lcc}
\hline Group & Dose, $\mathbf{m g} /$ ear & Weight of Ear, mg \\
\hline Control & - & $12 \pm 0.81$ \\
Indomethacin & 0.5 & $6.1 \pm 1.50$ \\
$\begin{array}{l}\text { Hydroalcoholic } \\
\begin{array}{l}\text { Extract of Stachys } \\
\text { Pilifera }\end{array}\end{array}$ & \\
& 1 & $4.4 \pm 0.85^{\mathrm{b}}$ \\
& 2.5 & $4 \pm 0.90^{\mathrm{c}}$ \\
& 5 & $3 \pm 0.70^{\mathrm{d}}$ \\
\hline
\end{tabular}

\footnotetext{
a Values are expressed as Mean \pm S.E.M. $(\mathrm{n}=6)$.

b $\mathrm{P}<0.05$ statistically significant relative to the control.

c $\mathrm{P}<0.01$ statistically significant relative to the control.

$\mathrm{d}_{\mathrm{P}}<0.001$ statistically significant relative to the control.
} 


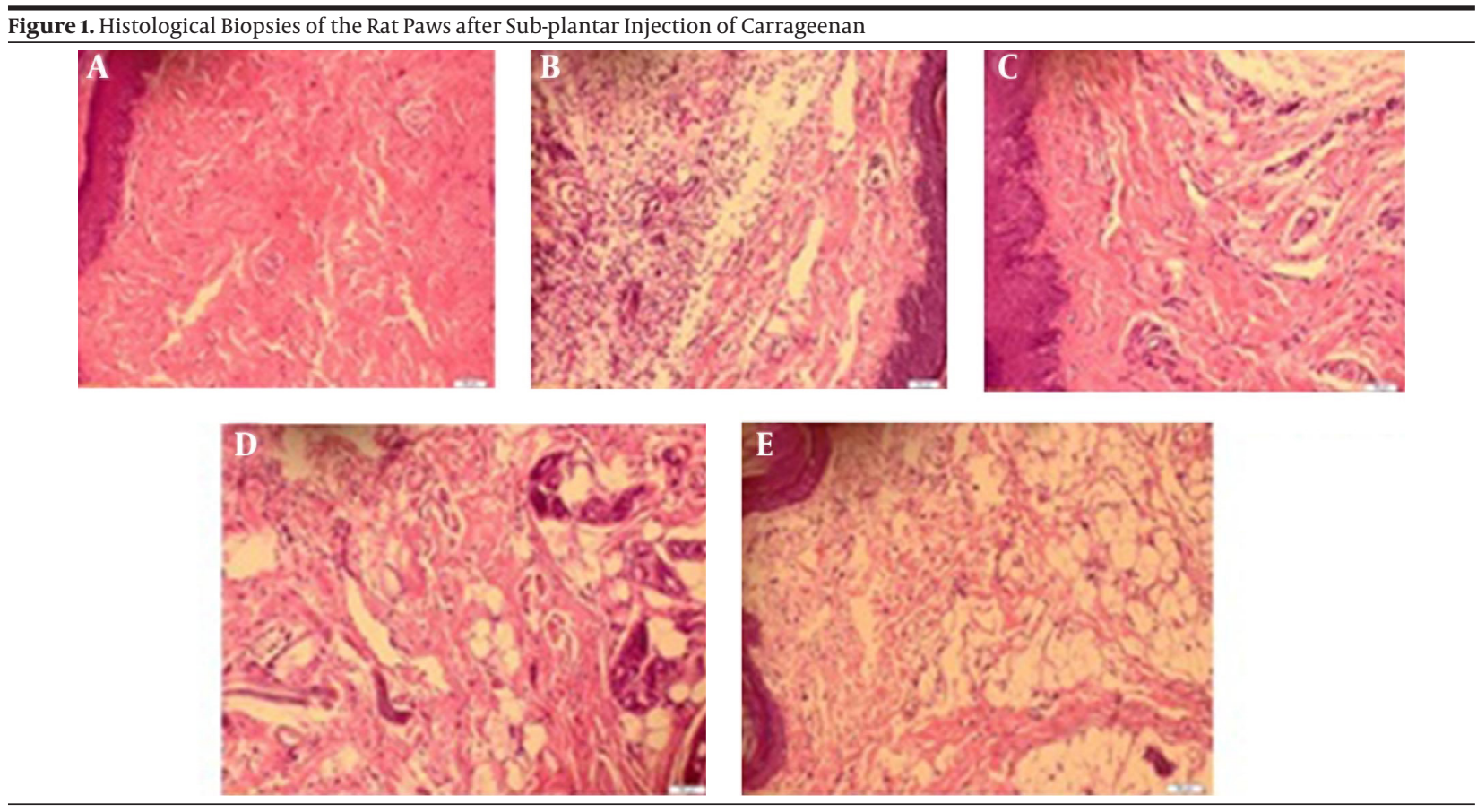

(A) Normal Paw. (B)Carrageenan Caused Edema, Congestion and Infiltration of Leukocytes Especially Neutrophils into the Paw Tissues. (C) Indomethacin $(10 \mathrm{mg} / \mathrm{kg}$, oral.) Decreased Paw Swelling and Infiltration of Neutrophils. Oral Pretreatment of Rats with Hydroalcoholic Extract of Stachys Pilifera at 100 (D) and 200 (E) mg/kg Doses Reduced Development of Swelling and Infiltration of Neutrophils, Compared with Carrageenan-injected Paw.
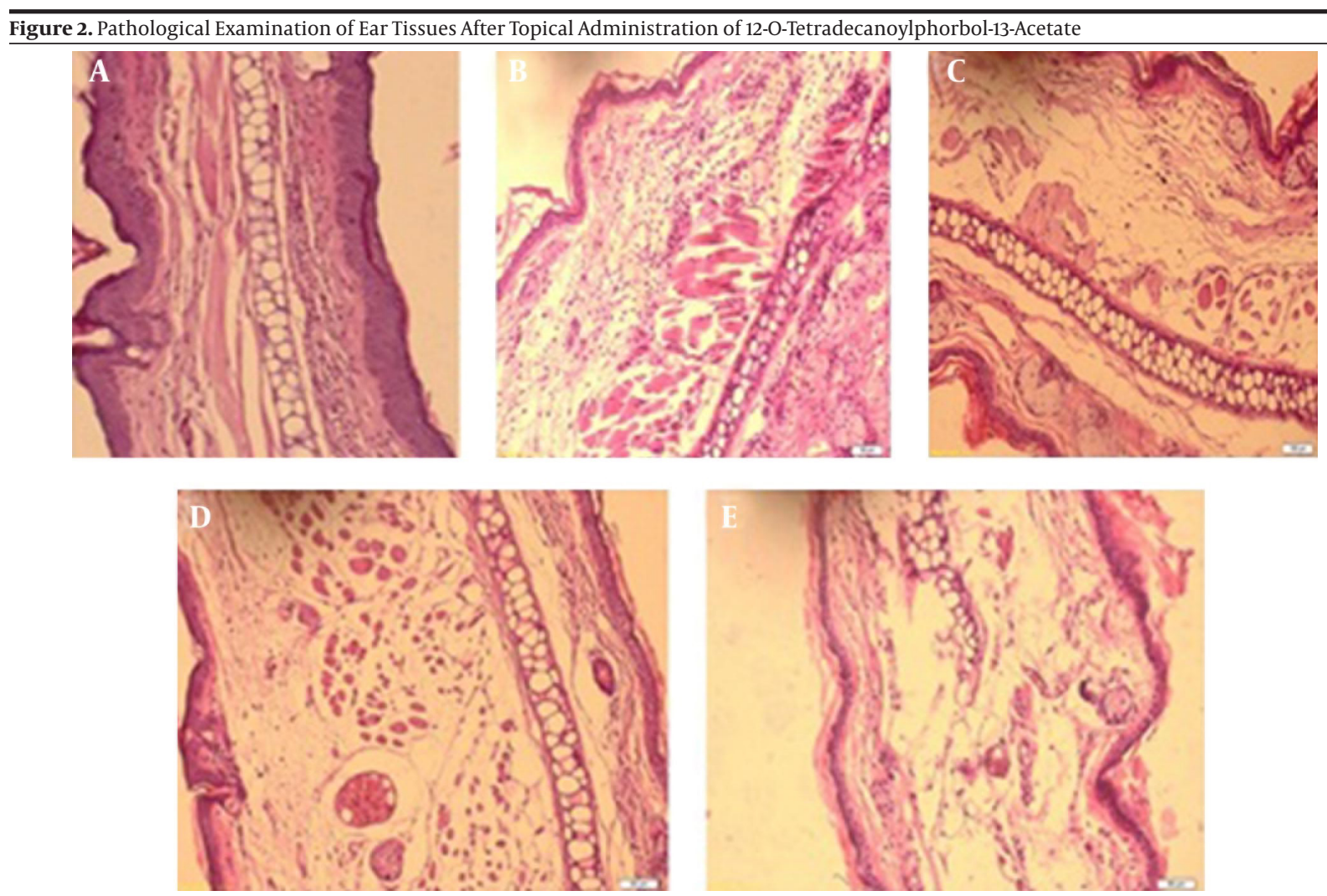

(A) Normal Ear, (B) Control: Topical Application of 12-O-Tetradecanoylphorbol-13-Acetate (2.5 $\mu \mathrm{g} /$ ear), Induced Inflammatory Lesion with Edema, Infiltration of Polymorphonuclear Leukocytes and Epidermal Hyperplasia. (C) Indomethacin ( $0.5 \mathrm{mg} / \mathrm{ear}$ ) Decreased the Indicated Changes. Topical Application of the Hydroalcoholic Extract of Stachys Pilifera at Doses of 2.5 (D) and 5(E) mg/ear with Simultaneous Administration of 12-O-Tetradecanoylphorbol-13-Acetate Was Able to Decrease Epidermis Thickness, Edema, and Infiltration of Polymorphonuclear Leukocytes. Sections Were Stained with Hematoxyline and Eosin, Magnification $\times 20$. 


\subsection{Ulcerogenic Effect of HESP}

According to the gastric evaluation, treatment of rats with HESP at doses of 50,100, 200, and $400 \mathrm{mg} / \mathrm{kg}$ (in the carrageenan test) did not produce any gastric lesions or bleeding compared to the vehicle-treated group.

\subsection{Acute Toxicity}

During $48 \mathrm{~h}$ following oral administration of HESP $(1000,3000,5000 \mathrm{mg} / \mathrm{kg})$, no behavior changes or death occurred. These results indicated that the LD50 value of HESP was greater than $5000 \mathrm{mg} / \mathrm{kg}$.

\section{Discussion}

In the present study, oral administration of HESP showed potent anti-inflammatory effects in different animal models of inflammation, including carrageenan- and formalin-induced paw edema in rat and TPA- or xylene-evoked ear edema in mouse. The carrageenaninduced paw edema is a time-dependent and biphasic inflammation reaction that various inflammatory mediators participate in its progress (31). The first phase of inflammation (0-1 hour) is related to the release of histamine, bradykinin, serotonin, and cyclooxygenase (COX) products $(32,33)$, while the late phase of edema is linked with the infiltration of PMN leucocytes, release of prostaglandins, and production of oxygen-derived free radicals $(32,34)$.

HESP (100 and $200 \mathrm{mg} / \mathrm{kg}$ ) elicits prominent inhibitory effects on the development of paw swelling in the two phases of the carrageenan test. Therefore, it is plausible that HESP reduces the release of pro-inflammatory mediators involved in the two phases of the carrageenan challenge. These results supported previous work showing that a hydroalcoholic extract of other species of Stachys such as Stachys inflata Benth and Stachys byzanthina C. Koch produced anti-inflammatory effects in vivo conditions $(16,17)$. In the formalin test, oral administration HESP similar to indomethacin (as a reference drug) attenuated the development of paw edema, lasting for 24 hours, indicating its long duration of action. It is reported that similar to carrageenan test, subplantar injection of formalin also produces a biphasic event.

During the initial phase (also called neurogenic phase) substance $\mathrm{P}$ and bradykinin are released, while in the second phase histamine, serotonin, prostaglandins, and bradykinin are involved (35). Anti-inflammatory effect of HESP on the formalin test, particularly in the neurogenic phase, led us to evaluate the effect of extract in another neurogenic inflammatory test (xylene-induced ear edema). Topical application of HESP suppressed xyleneinduced ear edema. Xylene-induced ear edema causes severe vasodilation and increases vascular permeability associated with substance P (36). Substance P, as a neurotransmitter, spreads all over the CNS. Furthermore, substance $\mathrm{P}$ generates neurogenic inflammation when peripherally stimulated. Xylene-induced swelling is followed by innate immunity response of the skin, a cytotoxicity reaction of activated T cells and then migration of PMN leucocytes which augment swelling and heaviness of the ear (37). Taken together, the results of anti-inflammatory effects of HESP on both formalin and xylene tests suggest that it inhibits neurogenic inflammation through suppressing the release or action of neuro-mediators especially substance $P$.

Finally, the topical application of HESP, exhibited a noticeable antiedematogenic effect in TPA-induced ear edema in mice. TPA-induced ear edema is a valuable model of skin inflammation for assessment of local and systemic anti-inflammatory agents (23). TPA develops local inflammation through leucocyte infiltration and generation of ROS because of activation of protein kinase $\mathrm{C}$ (PKC). This enzyme makes active the other enzymatic pathways such as phospholipase A2 (PLA2) and mitogen activated protein kinases (MAPK), resulting in the release of platelet activation factor (PAF) and arachidonic acid. These series of events either induce vasodilatation, vascular permeability, and discharge of serotonin and histamine or initiate production of prostaglandins and leukotrienes via COX and 5-lipoxygenase (5-LOX) enzymes, respectively $(38,39)$.

Peptic ulcer is one of the most important adverse effects of NSAIDs. This side effect of NSAIDs is linked to their ability to inhibit COX-1, which catalyzes the synthesis of prostaglandins (6). Macroscopic examination of the gastric mucosa in the extract-treated groups (in the carrageenan test) showed no tissue injuries or hemorrhage. Hence, the anti-inflammatory properties without gastric damage led us to suppose that the active components of HESP did not inhibit COX-1. COX enzymes catalyze the synthesis of prostaglandins and thromboxanes from arachidonic acid that released by most cell types (40-42). Two isoforms of COX have been identified, COX-1 and COX-2 (40). COX-2 is often considered as the inducible isoform of COX, since levels of COX-2 increase in response to various types of tissue stimulation (42). Bearing in mind that the production of arachidonic acid metabolites via the COX-2 enzyme is the main reason for developing of the inflammation in the early and late phases of the carrageenaninduced edema, the results of TPA test propose that the anti-inflammatory activity of HESP is probably related to inhibition of synthesis of COX-2 products.

PMN cells migration have a crucial role in the second phase of the carrageenan-induced inflammation and TPA-induced ear edema (43). In addition, the pathological evaluation of inflamed tissues (paws and ears) showed that HESP inhibited infiltration of PMN leucocytes into the site of inflammation. Therefore, another possibility is that HESP exerts its anti-inflammatory effect partly through the inhibition of leukocytes infiltration. Literature review showed the existence of phenolic compounds such as polyphenols, phenolic acids, flavonoids, iridoids, and phenylethanoid glycosides in the plants of the genus Stachys $(44,45)$. These compounds are usually water-sol- 
uble and the presence of them in the extract may be the major reason of its significant anti-inflammatory activity. It is important to notice that the extract in the higher dose $(400 \mathrm{mg} / \mathrm{kg}$ ) failed to suppress the development of carrageenan-induced paw edema.

This finding is consistent with the previous study about Stachys inflata. Maleki et al. reported that the hydroalcoholic extract of Stachys inflata at the dose of $400 \mathrm{mg} / \mathrm{kg}$ could not prevent the carrageenan-evoked paw edema in rats (17). The discrepancy between the inhibitory effect at low doses and lack of effectiveness at higher dose might be interpreted by this theory that some of the active component(s) of Stachys pilifera at high doses elicited pro-inflammatory activities (17).

In conclusion, the results of the present study demonstrated systemic and local anti-inflammatory effects of Stachys pilifera in animal models of inflammation. These findings should be taken as a base for further investigation on the exact mode of action of individual constituents of the extract.

\section{Acknowledgements}

We thank Yasuj University of Medical Sciences for financial support, and all the persons who helped us in this work.

\section{Authors' Contributions}

Study concept and design: Sadeghi, Zarezade, and Sadeghi; Analysis and interpretation of data: Sadeghi, Zarezade, and Akbartabar Toori; Drafting of the manuscript: Sadeghi, Zarezade, Sadeghi, Ghavamizadeh, and Azizi; and Critical revision of the manuscript for important intellectual content: Sadeghi, Zarezade, Mostafazadeh and Jafari Barmak.

\section{References}

1. Medzhitov R. Origin and physiological roles of inflammation. Nature. 2008;454(7203):428-35.

2. Yamada DM, Topol EJ. Importance of microembolization and inflammation in atherosclerotic heart disease. Am Heart J. 2000;140(6 Suppl):S90-102.

3. Reuter S, Gupta SC, Chaturvedi MM, Aggarwal BB. Oxidative stress, inflammation, and cancer: how are they linked? Free Radic Biol Med. 2010;49(11):1603-16.

4. Frode TS, Buss Zda S, dos Reis GO, Medeiros YS. Evidence of anti-inflammatory effects of pioglitazone in the murine pleurisy model induced by carrageenan. Int Immunopharmacol. 2009;9(12):1394-400.

5. Rainsford KD. Anti-inflammatory drugs in the 21st century. Subcell Biochem. 2007;42:3-27.

6. Ng SC, Chan FK. NSAID-induced gastrointestinal and cardiovascular injury. Curr Opin Gastroenterol. 2010;26(6):611-7.

7. Kumar D, Bhat ZA, Kumar V, Khan NA, Chashoo IA, Zargar MI, et al. Effects of Stachys tibetica essential oil in anxiety. Eur J Integr Med. 2012;4(2):e169-76.

8. Zargari A. Medicinal plants.Tehran: Tehran University Press; 1992.

9. Rechinger KH. Flora iranica: Akad Druck und Verlag Anst;1987.

10. Javidnia K, Miri R, Moein MR, Kamalinejad M, Sarkarzadeh H. Constituents of the essential oil of Stachys pilifera Benth. from Iran.J Essent Oil Res. 2006;18(3):275-7.

11. Garjani A, Maleki N, Nazemiyeh H. Effects of hydroalcoholic ex- tract from aerial parts of the sterile stems of Stachys inflata on myocardial infarct size in rats. Iran JPharm Res. 2010;2(3):165-70.

12. Biglar M, Shams Ardekani MR, Khanavi M, Shafiee A, Rustaiyan A, Salimpour F, et al. Comparison of the Volatile Composition of Stachys pubescence Oils Obtained by Hydro Distillation and Steam Distillation. PakJ Biol Sci. 2014;17(7):942-6.

13. Hajhashemi V, Ghannadi A, Sedighifar S. Analgesic and antiinflammatory properties of the hydroalcoholic, polyphenolic and boiled extracts of Stachys lavandulifolia. Res Pharm Sci. 2007;1(2):92-8.

14. Sonboli A, Salehi P, Ebrahimi Nejad S. Essential oil composition and antibacterial activity of the leaves of Stachys schtschegleevii from Iran. Chem Nat Compd. 2005;41(2):171-4.

15. Ebrahimabadi AH, Mazoochi A, Kashi FJ, Djafari-Bidgoli Z, Batooli H. Essential oil composition and antioxidant and antimicrobial properties of the aerial parts of Salvia eremophila Boiss. from Iran. Food Chem Toxicol. 2010;48(5):1371-6.

16. Khanavi M, Sharifzadeh M, Hadjiakhoondi A, Shafiee A. Phytochemical investigation and anti-inflammatory activity of aerial parts of Stachys byzanthina C. Koch. J Ethnopharmacol. 2005;97(3):463-8.

17. Maleki N, Garjani A, Nazemiyeh H, Nilfouroushan N, Eftekhar Sadat AT, Allameh Z, et al. Potent anti-inflammatory activities of hydroalcoholic extract from aerial parts of Stachys inflata on rats. $J$ Ethnopharmacol. 2001;75(2-3):213-8.

18. Farjam MH, Khalili M, Rustayian A, Javidnia K, Izadi S. Biological activity of the n-butanolic extract of Stachys pilifera. Afr J Microbiol Res. 2011;5:5115-9.

19. Masresha B, Makonnen E, Debella A. In vivo anti-inflammatory activities of Ocimum suave in mice. J Ethnopharmacol. 2012;142(1):201-5.

20. Babu NP, Pandikumar P, Ignacimuthu S. Anti-inflammatory activity of Albizia lebbeck Benth., an ethnomedicinal plant, in acute and chronic animal models of inflammation.J Ethnopharmacol. 2009;125(2):356-60.

21. Dewanjee S, Dua TK, Sahu R. Potential anti-inflammatory effect of Leea macrophylla Roxb. leaves: a wild edible plant. Food Chem Toxicol. 2013;59:514-20.

22. Hajhashemi V, Sadeghi H, Minaiyan M, Movahedian A, Talebi A. The role of central mechanisms in the anti-inflammatory effect of amitriptyline on carrageenan-induced paw edema in rats. Clinics (Sao Paulo). 2010;65(11):1183-7.

23. Sadeghi H, Mostafazadeh M, Sadeghi H, Naderian M, Barmak MJ, Talebianpoor MS, et al. In vivo anti-inflammatory properties of aerial parts of Nasturtium officinale. Pharm Biol. 2014;52(2):169-74.

24. Hajhashemi V, Sadeghi H, Minaiyan M, Movahedian A, Talebi A. Effect of fluvoxamine on carrageenan-induced paw edema in rats evaluation of the action sites. Iran J Pharm Res. 2011;10(3):611-8.

25. Hajhashemi V, Sadeghi H, Minaiyan M, Movahedian A, Talebi A. Central and peripheral anti-inflammatory effects of maprotiline on carrageenan-induced paw edema in rats. Inflamm Res. 2010;59(12):1053-9.

26. Fotio AL, Dimo T, Nguelefack TB, Dzeufiet PD, Ngo Lemba E, Temdie RJ, et al. Acute and chronic anti-inflammatory properties of the stem bark aqueous and methanol extracts of Sclerocarya birrea (Anacardiaceae). Inflammopharmacology. 2009;17(4):229-37.

27. Ahn EH, Kim DW, Kang HW, Shin MJ, Won MH, Kim J, et al. Transduced PEP-1-ribosomal protein S3 (rpS3) ameliorates 12-O-tetradecanoylphorbol-13-acetate-induced inflammation in mice. Toxicology. 2010;276(3):192-7.

28. Shang X, Wang J, Li M, Miao X, Pan H, Yang Y, et al. Antinociceptive and anti-inflammatory activities of Phlomis umbrosa Turcz extract. Fitoterapia. 2011;82(4):716-21.

29. Akkol EK, Yalcin FN, Kaya D, Calis I, Yesilada E, Ersoz T. In vivo antiinflammatory and antinociceptive actions of some Lamium species. J Ethnopharmacol. 2008;118(1):166-72.

30. Kumar D, Bhat ZA, Shah MY. Effect of successive extracts of Stachys tibetica Vatke (Lamiaceae) in anxiety. Orient Pharm Exp Med. 2012;12(4):247-53.

31. Chavan MJ, Wakte PS, Shinde DB. Analgesic and anti-inflamma- 
tory activity of Caryophyllene oxide from Annona squamosa L. bark. Phytomedicine. 2010;17(2):149-51.

32. Sonika G, Manubala R, Deepak J. Comparative studies on antiinflammatory activity of Coriandrum Sativum, Datura stramonium and Azadirachta Indica. Asian J Exp Biol Sci. 2010;1(1):151-4

33. Sadeghi H, Hajhashemi V, Minaiyan M, Movahedian A, Talebi A. Further studies on anti-inflammatory activity of maprotiline in carrageenan-induced paw edema in rat. Int Immunopharmacol. 2013;15(3):505-10.

34. Vircheva S, Nenkova G, Georgieva A, Alexandrova A, Tzvetanova E, Mateeva P, et al. Effects of desipramine on the antioxidant status in rat tissues at carrageenan-induced paw inflammation. Cell Biochem Funct. 2011.

35. Sreejamole KL, Radhakrishnan CK, Padikkala J. Anti-inflammatory activities of aqueous/ethanol and methanol extracts of Perna viridis Linn. in mice. Inflammopharmacology. 2011;19(6):335-41.

36. Richardson JD, Vasko MR. Cellular mechanisms of neurogenic inflammation. J Pharmacol Exp Ther. 2002;302(3):839-45.

37. Kodithuwakku ND, Pan M, Zhu YL, Zhang YY, Feng YD, Fang WR, et al. Anti-inflammatory and antinociceptive effects of Chinese medicine SQ gout capsules and its modulation of pro-inflammatory cytokines focusing on gout arthritis. J Ethnopharmacol. 2013;150(3):1071-9.

38. Boller S, Soldi C, Marques MC, Santos EP, Cabrini DA, Pizzolatti
MG, et al. Anti-inflammatory effect of crude extract and isolated compounds from Baccharis illinita DC in acute skin inflammation.J Ethnopharmacol. 2010;130(2):262-6.

39. Kalyan Kumar G, Dhamotharan R, Kulkarni NM, Mahat MY, Gunasekaran J, Ashfaque M. Embelin reduces cutaneous TNF-alpha level and ameliorates skin edema in acute and chronic model of skin inflammation in mice. EurJ Pharmacol. 2011;662(1-3):63-9.

40. Feletou M, Huang Y, Vanhoutte PM. Vasoconstrictor prostanoids. Pflugers Arch. 2010;459(6):941-50.

41. Turini ME, DuBois RN. Cyclooxygenase-2: a therapeutic target Annu Rev Med. 2002;53:35-57.

42. Aid S, Bosetti F. Targeting cyclooxygenases-1 and -2 in neuroinflammation: Therapeutic implications. Biochimie. 2011;93(1):46-51.

43. Sadeghi H, Hajhashemi V, Minaiyan M, Movahedian A, Talebi A. A study on the mechanisms involving the anti-inflammatory effect of amitriptyline in carrageenan-induced paw edema in rats. Eur J Pharmacol. 2011;667(1-3):396-401.

44. Meremeti A, Karioti A, Skaltsa H, Heilmann J, Sticher O. Secondary metabolites from $<\mathrm{i}>$ Stachys ionica $<\mid \mathrm{i}>$. Biochemical systematics and ecology. 2004;32(2):139-51.

45. Bilusic Vundac V, Brantner AH, Plazibat M. Content of polyphenolic constituents and antioxidant activity of some Stachys taxa. Food chemistry. 2007;104(3):1277-81. 